\title{
The study in cockscomb mineral composition
}

\author{
A. S. Deyneka iD B,C,D, V. V. Protska iD*A,C,D,E, I. O. Zhuravel iDA,E,F, O. A. Kyslychenko iD B, V. Yu. Kuznietsova IDE \\ National University of Pharmacy, Kharkiv, Ukraine
}

A - research concept and design; B - collection and/or assembly of data; C - data analysis and interpretation; D - writing the article;

$\mathrm{E}$ - critical revision of the article; $\mathrm{F}$ - final approval of the article

Cockscomb (Celosia cristata (L.) Kuntze) is grown in Ukraine mostly as a decorative plant. According to literature, it contains phenolic, terpenic, steroid, and nitrogen-containing compounds, showing a large range of biological activity.

The aim of the work was to study qualitative composition and determination of quantitative content of mineral elements in cockscomb roots, stems, leaves, flowers, and seeds.

Materials and methods. The mineral composition of cockscomb raw material was studied by atomic absorption spectroscopy.

Results. In cockscomb roots, stems, leaves, flowers, and seeds 19 mineral elements were identified and determined. The bulk of mineral elements was accumulated in cockscomb leaves $-11580.54 \pm 289.51 \mu \mathrm{g} / 100 \mathrm{~g}$. In all samples of the herb potassium dominated within the limits of $1125.00 \pm 28.12 \mu \mathrm{g} / 100 \mathrm{~g}$ to $7000.00 \pm 175.00 \mu \mathrm{g} / 100 \mathrm{~g}$. Prevailing microelements were iron in plant roots and seeds $(210.00 \pm 5.25 \mu \mathrm{g} / 100 \mathrm{~g}$ and $81.00 \pm 2.02 \mu \mathrm{g} / 100 \mathrm{~g}$ respectively), aluminum in leaves and flowers $(215.00 \pm 2.25 \mu \mathrm{g} / 100 \mathrm{~g}$ and $44.00 \pm 1.10 \mu \mathrm{g} / 100 \mathrm{~g}$ respectively), zinc in stems $(5.70 \pm 0.14 \mu \mathrm{g} / 100 \mathrm{~g})$. Besides, such microelements as zinc $(53.00 \pm 1.33 \mu \mathrm{g} / 100 \mathrm{~g})$ and strontium $(21.20 \pm 0.53 \mu \mathrm{g} / 100 \mathrm{~g})$ were mostly accumulated in roots, manganese $(27.00 \pm 0.68 \mu \mathrm{g} / 100 \mathrm{~g})$ in leaves, copper $(2.00 \pm 0.05 \mu \mathrm{g} / 100 \mathrm{~g})$ in flowers. The content of heavy metals was within the limits stipulated in Ukrainian Pharmacopoeia.

Conclusions. The obtained results will be used in the standardization of cockscomb raw material and in the development of medicines on the basis of this raw material.

Key words: cockscomb, Amaranthaceae, absorption spectrometry, minerals.

Current issues in pharmacy and medicine: science and practice 2021; 14 (2), 194-199

\section{Дослідження мінерального складу целозії гребінчастої}

\section{А. С. Дейнека, В. В. Процька, І. О. Журавель, О. А. Кисличенко, В. Ю. Кузнєцова}

Целозію гребінчасту (Celosia cristata (L.) Kuntze) вирощують в Україні здебільшого як декоративну рослину. За даними фахової літератури, вона містить фенольні, терпенові, стероїдні та нітрогенвмісні сполуки, має широкий спектр біологічної активності.

Мета роботи - дослідження якісного складу та визначення кількісного вмісту мінеральних елементів у коренях, стеблах, листі, квітках і насінні целозії гребінчастої.

Матеріали та методи. Мінеральний склад сировини целозії гребінчастої досліджували методом атомно-абсорбційної спектроскопії.

Результати. У коренях, стеблах, листі, квітках і насінні целозії гребінчастої ідентифікували та визначили вміст 19 мінеральних елементів. Встановили, що найбільша кількість мінеральних елементів накопичувалася в листі целозії гребінчастої $11580,54 \pm 289,51$ мкг/100г. У всіх зразках сировини елемент, що домінує, -калій, його вміст становив від 1125,00 $\pm 28,12$ мкг/100 г до 7000,00 \pm 175 мкг/100 г. Серед мікроелементів за вмістом у коренях і насінні цієї рослини кількісно переважав ферум (210,00 \pm 5,25 мкг/100 г та 81,00 $\pm 2,02$ мкг/100 г відповідно), у листі та квітках -алюміній $(215,00 \pm 2,25$ мкг/100 г та 44,00 $\pm 1,10$ мкг/100 г відповідно), у стеблах - цинк (5,70 \pm 0,14 мкг/ 100 г). Крім того, такі мікроелементи, як цинк (53,00 \pm 1,33 мкг/100 г) і стронцій $(21,20 \pm 0,53$ мкг/100 г) максимально накопичувалися в коренях, манган $(27,00 \pm 0,68$ мкг/100 г) - у листі, купрум (2,00 \pm 0,05 мкг/100 г) - у квітках. Концентрації важких металів - у межах припустимих за вимогами ДФУ.

Висновки. Результати дослідження будуть використані під час стандартизації сировини целозії гребінчастої та впродовж розроблення лікарських рослинних засобів на основі цієї сировини.

Ключові слова: целозія гребінчаста, амарантові, абсорбційна спектрометрія, мінерали.

Актуальні питання фармацевтичної і медичної науки та практики. 2021. Т. 14, № 2(36). С. 194-199

ARTICLE

INFO

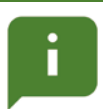

http:l/pharmed.

zsmu.edu.ualarticle

view/230561
UDC $615.32 \cdot 54.061 / 062 \cdot 582.663 .2$

DOI: $10.14739 / 2409-2932.2021 .2 .230561$

Current issues in pharmacy and medicine: science and practice 2021; 14 (2), 194-199

Key words: cockscomb, Amaranthaceae, absorption spectrometry, minerals.

*E-mail: vvprotskaya@gmail.com

Received: 29.03.2021 // Revised: 23.04.2021 // Accepted: 27.04.2021 


\title{
Исследование минерального состава целозии гребенчатой
}

\author{
А. С. Дейнека, В. В. Процкая, И. А. Журавель, А. А. Кисличенко, В. Ю. Кузнецова
}

Целозию гребенчатую (Celosia cristata (L.) Kuntze) выращивают в Украине преимущественно как декоративное растение. По данным научной литературы, она содержит френольные, терпеновые, стероидные и азотсодержащие соединения, проявляет широкий спектр биологической активности.

Цель работы - исследование качественного состава и определение количественного содержания минеральных элементов в корнях, стеблях, листьях, цветках и семенах целозии гребенчатой.

Материалы и методы. Минеральный состав сырья целозии гребенчатой исследовали методом атомно-абсорбционной спектроскопии.

Результаты. В корнях, стеблях, листьях, цветках и семенах целозии гребенчатой идентифицировали и определили содержание 19 минеральных элементов. Установлено, что наибольшее количество минеральных элементов накапливалось в листьях целозии гребенчатой - 11580,54 $\pm 289,51$ мкг/100 г. Во всех образцах сырья доминирующий элемент - калий, его содержание составляло от $1125,00 \pm 28,12$ до 7000,00 $\pm 175,00$ мкг/100 г. Среди микроэлементов по содержанию в корнях и семенах этого растения преобладало железо (210,00 $\pm 5,25$ мкг/100 г и 81,00 $\pm 2,02$ мкг/100 г соответственно), в листьях и цветках -алюминий (215,00 $\pm 2,25$ мкг/100 г и 44,00 \pm 1,10 мкг/100 г соответственно), в стеблях - цинк (5,70 $\pm 0,14$ мкг/100 г). Кроме того, такие микроэлементы, как цинк (53,00 \pm 1,33 мкг/100 г) и стронций $(21,20 \pm 0,53$ мкг/100 г) в максимальном количестве содержались в корнях, марганец $(27,00 \pm 0,68$ мкг/100 г) - в листьях, медь $(2,00 \pm 0,05$ мкг/100 г) - в цветках. Содержание тяжелых металлов - в пределах допустимых концентраций по требованиям ГФУ.

Выводы. Результаты исследования будут использованы при стандартизации сырья целозии гребенчатой и в ходе разработки лекарственных растительных средств на основе этого сырья.

Ключевые слова: целозия гребенчатая, амарантовые, абсорбционная спектрометрия, минералы.

Актуальные вопросы фрармацевтической и медицинской науки и практики. 2021. Т. 14, № 2(36). С. 194-199

Mineral elements are important in the provision of a human organism's normal function. Such mineral elements as sodium and potassium are present in interstitial liquors, they support homeostasis, normalize arterial pressure. Abnormally low potassium concentration in blood plasma leads to hypokalemia and osteoporosis, increases risks of a stroke [1-3]. Sodium deficit causes hyponatremia which may lead to renal and cardiac disease, provokes cerebral edema with corresponding neurological consequences [1]. Calcium participates in nerve impulse transmissions, it is a structural component of conjunctive tissue and ensures bone strength $[1,3]$. Copper, iron, manganese, selenium, and zinc are hormone and enzyme cofactors, participating in numerous biochemical reactions in organism [3,4].

Copper controls free radical reactions and lipid peroxidation processes. Copper deficit affects the antioxidant system which leads to an increase of active oxygen forms level, damage of lipids, proteins, and DNA, provokes liver fatty degeneration, and favors high cholesterol concentration in blood plasma [1,2]. Cobalt and iodine participate in red blood cell formation [4]. Iron as a component of hemoglobin and cytochromes supports cell respiration [3]. Molybdenum activates antioxidant enzymes [4]. Copper, selenium, and zinc control humoral immunity and increase organism resistivity [4]. Iodine deficit leads to goiter, irreversible mental deficiency, reproductive insufficiency $[1,5]$. As the human organism is unable to produce mineral elements, they must be introduced with food or replenished by taking medicines $[1,4]$.

On a par with this, in the evaluation of medicinal herbs equally important is the content of heavy metals. Such elements as lead, cobalt, mercury, arsenic, cadmium, etc., may accumulate in body tissues, and their excess leads to intoxication with severe consequences. Under chronic intoxication with mercury compounds, we witness mental disorders, encephalopathy, vision and hearing disorders, tremor, tachycardia, nephrosis, and gastroenteritis $[3,6,7]$. Cadmium excess in organisms leads to osteoporosis, anemia, hypertension, nephropathy, cardiopathy, liver lesions. Toxic lead doses hinder hemopoiesis processes, cause anemia, nephropathy, encephalopathy [3,6,7]. Arsenic compounds affect the nervous system, hemolyzed red cells, and cause severe forms of cardiac, renal, and hepatic insufficiency $[6,7]$. Besides, cadmium and lead ions displace calcium, iron, copper, zinc, and magnesium ions from biological structures, such as hemoglobin and enzymes, thus destroying hemopoiesis, affecting nervous, cardiovascular, and locomotor systems [8].

Therefore, the content of heavy metals in medicinal herbs and in food products is strictly limited by the Ukrainian Food Product Safety and Quality Basic Principles and Requirements Act, Order of Ukrainian Ministry of Health on State Sanitary Norms and Regulations "Medical Requirements to Quality and Safety of Food Products and Food Raw Materials" No 1140 of 09.01.2013 and General Article 2.4.27 "Heavy Metals in Medicinal Herbs and Plant-based Medicines" of Ukrainian Pharmacopoeia 2.0.1 $[9,10]$.

Genus Celosia (Celosia cristata L.) belongs to the Amaranthaceae family (Amaranthaceae L.) and includes about 60 species which are popular at all continents for landscape decoration, whereas in West Africa, North America, China, Indonesia, India they are cultivated as food plants $[1,11,12]$. Their name means "fiery, lurid" and corresponds to the peculiar shape and bright coloring of inflorescences [13,14]. Cockscomb (Celosia cristata (L.) Kuntze) some authors treat 
as a subspecies of quail grass $[11,15]$, whereas others rank it as a separate species $[1,12,13]$.

In South East Asia flowers of this plant serve as medicines from hypertension, dysentery, coughing, conjunctivitis, blood diseases, oral cavity infections, menstrual pains, menostasia, intestinal, pulmonary and hemorrhoid bleedings [11]. Many researchers specify that celosias display anti-diabetes, anti-inflammatory, anti-oxidant, anti-microbial, anti-sun, anti-diarrhea, anti-helminthic, liver protecting effect as well as stimulate immunity $[12,16]$.

As follows from the literature, overground parts of cockscomb contain mainly steroid and phenolic compounds, including flavonoids cochliophylin and cristatein $[13,14]$. Its leaves accumulate glycoproteins at the time of blossoming. From cockscomb inflorescences nitrogen-containing pigments betacyanin and betaxanthin (celosianin I and celosianin II) were extracted [12,13,17]. Flowers are also known to contain carbohydrates, amino acids and phenolic compounds $[13,14]$. From cockscomb seeds saponins cristatain, celosine $\mathrm{A}$, celosine $\mathrm{B}$, celosine $\mathrm{C}$ and celosine $\mathrm{D}$, as well as semenoside $\mathrm{A}$, glycoproteins, $\beta$-sitosterol and stigmasterol were extracted $[12,17]$. Also its seeds contain kaempferol and quercetin [13]. Researchers from India, China, South Africa studied mineral composition of cockscomb and related species $[1,12,18]$.

In cockscomb flowers from India, six mineral elements were identified. According to this study, in cockscomb flowers potassium content $(520.40 \pm 1.12 \mathrm{mg} / 100 \mathrm{~g})$ was almost four times higher than that of calcium $(128.68 \pm 1.53 \mathrm{mg} / 100 \mathrm{~g})$ and 6.8 times higher than that of magnesium (76.40 \pm $0.52 \mathrm{mg} / 100 \mathrm{~g}$ ). The content of sodium, zinc, and iron never exceeded $10 \mathrm{mg} / 100 \mathrm{~g}$ [12]. The study in mineral composition of quail grass leaves, stems, and flowers from India ascertained potassium $(30.55-37.66 \mathrm{mg} / \mathrm{g})$ and sodium $(0.52-1.06 \mathrm{mg} / \mathrm{g})$ content in those parts of the herb to be very close. Magnesium content $(67.18 \mathrm{mg} / \mathrm{g})$ was twice higher in leaves than in stems and flowers. Calcium content was almost identical in quail grass leaves and stems $(79.70-86.60 \mathrm{mg} / \mathrm{kg})$ and 5 times lower in flowers, whereas all samples of this raw material contained less than $0.52 \mathrm{mg} / \mathrm{kg}$ iron, zinc, and copper [19].

African samples of quail grass and wheat celosia showed as much as $178-242 \mathrm{mg} / 100 \mathrm{~g}$ calcium in leaves. Nevertheless, data on other elements substantially differ. Thus, leaves of wheat celosia contained $659 \mathrm{mg} / 100 \mathrm{~g}$ potassium, whereas those of quail grass contained 5 times less. Magnesium (463 mg/100 g) and phosphorus (102 mg/100 g) grossly prevailed in wheat celosia leaves. Quail grass leaves contained sodium (71.32 mg/100 g) and iron (15.25 mg/100 g) almost three times more than those of wheat celosia. Content of copper, zinc, and manganese in these plants never exceeded 8 $\mathrm{mg} / 100 \mathrm{~g}$ [1]. Other Indian authors determined the content of macro- and microelements in quail grass herb before, during, and after blossoming. Potassium prevailed in all samples within the range of 5995 to $10340 \mathrm{mg} / 100 \mathrm{~g}$. Calcium was concentrated in those samples within the limits $1365-1540 \mathrm{mg} / 100 \mathrm{~g}$. The content of magnesium $(755-765 \mathrm{mg} / 100 \mathrm{~g})$ and phos- phorus (645-845 mg/100 g) was almost identical. It should be noted that potassium, calcium, phosphorus, and copper $(1.70 \mathrm{mg} / 100 \mathrm{~g})$ mostly accumulated in quail grass herb before blossoming, the maximum content of magnesium, zinc $(12.30 \mathrm{mg} / 100 \mathrm{~g})$ and iron $(21.30 \mathrm{mg} / 100 \mathrm{~g})$ was during blossoming, sodium $(65.00 \mathrm{mg} / 100 \mathrm{~g})$, and manganese (7.65 mg/100 g) mostly accumulated after blossoming [18]. The chemical composition of plant bioactive substances is known to differ depending on the climatic conditions and vegetation area. Therefore, it is necessary to study the mineral composition of cockscomb grown in Ukraine.

\section{Aim}

The aim of the work was to study qualitative composition and determination of quantitative content of mineral elements in cockscomb roots, stems, leaves, flowers, and seeds.

\section{Materials and methods}

We used air-dried milled roots, stems, leaves, flowers, and seeds of cockscomb collected in the Kharkiv Region, Ukraine in 2019-2020 for the mineral composition study. Mineral composition of cockscomb raw material was studied by atomic absorption spectroscopy according to the method described in general article 2.0.1 "Atomic absorption spectroscopy" of Ukrainian Pharmacopoeia [20]. The research was performed on the basis on A. B. Blank Analytical Chemistry Department, Institute of Monocrystals, National Academy of Sciences of Ukraine, under the guidance of Junior Scientist Olena Hryshyna.

Charred at muffle furnace and treated with dilute sulfuric acid a sample of raw material (about $2 \mathrm{~g}$ ) was evaporated from graphite electrodes at intermittent current intensity. Arc discharge of this current was $16 \mathrm{~A}$, the exposition was $60 \mathrm{sec}$ [20]. Spectra were generated at IBC-28 unit at pressure 0.04 $\mathrm{MPa}$ and flame temperature $2250{ }^{\circ} \mathrm{C}[20]$. Spectra were registered at DFS-8 spectrograph with grating 600 grooves $/ \mathrm{mm}$ and a three-lens slit lighting system. The intensity of obtained spectra was measured with MF-1 microphotometer with firing phase $60{ }^{\circ} \mathrm{C}$, spectrograph slit width being $0.015 \mathrm{~mm}$. The firing impulse frequency was 100 discharges per second at spectrum range $230 \mathrm{~nm}$ to $347 \mathrm{~nm}$ [20].

Copper was dissolved in nitric acid, whereas all other elements were analyzed using chemically pure reagents and double-purified water. For all elements line and background, blackening differences were calculated $\left(\mathrm{S}=\mathrm{S}_{1+b g}-\mathrm{S}_{\mathrm{bg}}\right)$ for sample $\left(\mathrm{S}_{\mathrm{sam}}\right)$ and graduating standard $\left(\mathrm{S}_{\mathrm{GS}}\right)$ spectra. On the basis of these results, we have built a graduation plot in coordinates: average background $(\mathrm{S})$ and background $\left(\mathrm{S}_{\mathrm{GS}}\right)$ blackening average value - logarithm of element content in graduation standard $(\lg C)$, where $\mathrm{C}$ is expressed as a percent of basis [20].

The content of mineral elements in ashes ( $\mathrm{a}, \%$ ) was found from the plot. Element content in raw material (X, \%) was calculated by the formula: 
Table 1. Qualitative composition and quantitative content of mineral elements in cockscomb raw material

\begin{tabular}{|c|c|c|c|c|c|}
\hline \multirow{2}{*}{ Element } & \multicolumn{5}{|c|}{ Content of macro- and microelements in cockscomb raw material as absolutely dry raw material, $\mu \mathrm{g} / 100 \mathrm{~g}$} \\
\hline & Roots & Leaves & Stems & Flowers & Seeds \\
\hline \multicolumn{6}{|l|}{ Macroelements } \\
\hline Silicon & $1485.00 \pm 37.12$ & $270.00 \pm 6.75$ & $11.00 \pm 0.28$ & $175.00 \pm 4.38$ & $540.00 \pm 13.50$ \\
\hline Phosphorus & $32.00 \pm 0.80$ & $245.00 \pm 6.12$ & $57.00 \pm 1.42$ & $115.00 \pm 2.88$ & $110.00 \pm 2.75$ \\
\hline Magnesium & $635.00 \pm 15.88$ & $1080.00 \pm 27.00$ & $265.00 \pm 6.62$ & $265.00 \pm 6.62$ & $135.00 \pm 3.38$ \\
\hline Calcium & $1485.00 \pm 37.12$ & $2430.00 \pm 60.75$ & $920.00 \pm 23.00$ & $530.00 \pm 13.25$ & $160.00 \pm 4.00$ \\
\hline Sodium & $425.00 \pm 10.63$ & $190.00 \pm 4.75$ & $210.00 \pm 5.25$ & $44.00 \pm 1.10$ & $40.00 \pm 1.00$ \\
\hline Potassium & $5935.00 \pm 148.38$ & $7000.00 \pm 175.00$ & $3100.00 \pm 77.50$ & $2640.00 \pm 66.00$ & $1125.00 \pm 28.12$ \\
\hline Total macroelements & $9997.00 \pm 249.93$ & $11215.00 \pm 280.38$ & $4563.00 \pm 114.08$ & $3769.00 \pm 94.22$ & $2110.00 \pm 52.75$ \\
\hline \multicolumn{6}{|l|}{ Microelements } \\
\hline Iron & $210.00 \pm 5.25$ & $75.00 \pm 1.88$ & $4.60 \pm 0.12$ & $22.00 \pm 0.55$ & $81.00 \pm 2.02$ \\
\hline Aluminum & $210.00 \pm 5.25$ & $215.00 \pm 5.38$ & $1.00 \pm 0.03$ & $44.00 \pm 1.10$ & $54.00 \pm 1.35$ \\
\hline Manganese & $21.20 \pm 0.53$ & $27.00 \pm 0.68$ & $1.10 \pm 0.03$ & $4.00 \pm 0.10$ & $13.50 \pm 0.34$ \\
\hline Nickel & $0.21 \pm 0.01$ & $0.13 \pm 0.01$ & $<0.03$ & $0.07 \pm 0.01$ & $0.54 \pm 0.01$ \\
\hline Molybdenum & $0.21 \pm 0.01$ & $0.21 \pm 0.01$ & $0.11 \pm 0.01$ & $0.13 \pm 0.01$ & $0.09 \pm 0.01$ \\
\hline Copper & $0.70 \pm 0.02$ & $1.00 \pm 0.03$ & $0.52 \pm 0.01$ & $2.00 \pm 0.05$ & $0.78 \pm 0.02$ \\
\hline Zinc & $53.00 \pm 1.33$ & $27.00 \pm 0.67$ & $5.70 \pm 0.14$ & $8.80 \pm 0.22$ & $12.60 \pm 0.32$ \\
\hline Strontium & $21.20 \pm 0.53$ & $20.20 \pm 0.51$ & $2.50 \pm 0.06$ & $1.60 \pm 0.04$ & $0.22 \pm 0.01$ \\
\hline Total microelements & $516.52 \pm 12.91$ & $365.54 \pm 9.14$ & $15.53 \pm 0.39$ & $82.60 \pm 2.07$ & $162.73 \pm 4.07$ \\
\hline Grand total mineral elements & $10513.52 \pm 262.84$ & $11580.54 \pm 289.51$ & $4578.53 \pm 114.46$ & $3851.60 \pm 96.29$ & $2272.73 \pm 56.82$ \\
\hline \multicolumn{6}{|l|}{ Content of toxic elements } \\
\hline Lead & $<0.03$ & $<0.03$ & $<0.03$ & $<0.03$ & $<0.03$ \\
\hline Cobalt & $<0.03$ & $<0.03$ & $<0.03$ & $<0.03$ & $<0.03$ \\
\hline Cadmium & $<0.01$ & $<0.01$ & $<0.01$ & $<0.01$ & $<0.01$ \\
\hline Arsenic & $<0.01$ & $<0.01$ & $<0.01$ & $<0.01$ & $<0.01$ \\
\hline Mercury & $<0.01$ & $<0.01$ & $<0.01$ & $<0.01$ & $<0.01$ \\
\hline
\end{tabular}

$$
\mathrm{X}=\frac{\mathrm{a} \times \mathrm{m}_{1}}{\mathrm{~m}}
$$

where $\mathrm{m}_{1}$ - ash mass, $\mathrm{g}$;

$\mathrm{m}$ - raw material (dry) mass, g;

a - element content in ash, \% [20].

\section{Results}

According to the results of the mineral composition study in all samples of cockscomb raw material, we identified and determined 6 macroelements (silicon, phosphorus, magnesium, calcium, sodium, and potassium), 8 microelements (iron, aluminum, manganese, nickel, molybdenum, copper, zinc, and strontium) and 5 heavy metals (lead, cobalt, cadmium, arsenic, and mercury).

Qualitative composition and quantitative content of mineral elements in cockscomb raw material presented in Table 1.

\section{Discussion}

In the course of the research, we established that the bulk of mineral elements was accumulated in cockscomb leaves and roots that were $11580.54 \pm 289.51 \mu \mathrm{g} / 100 \mathrm{~g}$ and $10513.52 \pm 262.84 \mu \mathrm{g} / 100 \mathrm{~g}$ respectively. The total content of mineral elements in the stems $(4578.53 \pm 114.46 \mu \mathrm{g} / 100 \mathrm{~g})$ of tested plant was almost 2.5 times lower than that in its leaves. Flowers $(3851.60 \pm 96.29 \mu \mathrm{g} / 100 \mathrm{~g})$ of cockscomb contained 1.7 times more mineral elements than its seeds $(2272.73 \pm$ $56.82 \mu \mathrm{g} / 100 \mathrm{~g})$. Total mineral content increased from seeds, flowers, and stems up to roots and leaves. Microelements in cockscomb roots, leaves, stems, and flowers possess only $1 \%$ to $5 \%$ of total mineral content, and only in seeds, it reached as much as $7 \%$.

Quantitative content of identified mineral elements gradually decreased in succession $\mathrm{K}>\mathrm{Ca}>\mathrm{Mg}>\mathrm{Si}>\mathrm{P}>\mathrm{Al}$ $>\mathrm{Na}>\mathrm{Fe}>\mathrm{Zn}>\mathrm{Mn}>\mathrm{Sr}>\mathrm{Cu}>\mathrm{Mo}>\mathrm{Ni}$. A similar situation was observed in stems, roots, and seeds. 
Nevertheless, in stems sodium prevailed over phosphorus and silicon, zinc over iron. In seeds and roots potassium, silicon, calcium, and magnesium dominated. In seeds phosphorus prevailed over aluminum, sodium, and zinc, whereas in roots it was vice versa. Besides, seeds contained much more nickel than copper and strontium. This distribution can be explained by the physiological feature of the plant. They can capability to accumulate individual macro-and micronutrients in certain organs and tissues.

The highest content of macroelements was in cockscomb leaves that was $11215.00 \pm 280.38 \mu \mathrm{g} / 100 \mathrm{~g}$, that of microelements was in its roots $(516.52 \pm 12.91 \mu \mathrm{g} / 100 \mathrm{~g})$. At the same time, the leaves of the tested plant contained total microelements almost 1,5 times less (365.54 $\pm 9.14 \mu \mathrm{g} / 100 \mathrm{~g})$ than its roots.

Potassium was proved to prevail among macroelements in all tested samples of cockscomb herb, within the limits from $1125.00 \pm 28.12 \mu \mathrm{g} / 100 \mathrm{~g}$ in cockscomb seeds to $7000.00 \pm 175.00 \mu \mathrm{g} / 100 \mathrm{~g}$ in its leaves. The highest amount of silicon $(1485.00 \pm 37.12 \mu \mathrm{g} / 100 \mathrm{~g})$ and sodium $(425.00 \pm 10.63 \mu \mathrm{g} / 100 \mathrm{~g})$ was accumulated in cockscomb roots, that of phosphorus $(245.00 \pm 6.12 \mu \mathrm{g} / 100 \mathrm{~g})$, magnesium $(1080.00 \pm 27.00 \mu \mathrm{g} / 100 \mathrm{~g})$, calcium $(2430.00 \pm$ $60.75 \mu \mathrm{g} / 100 \mathrm{~g})$ was accumulated in its leaves.

Dominating microelements in cockscomb roots were iron and aluminum in almost identical amounts that was $210.00 \pm 5.25 \mu \mathrm{g} / 100 \mathrm{~g}$. Aluminum prevailed in leaves and flowers, iron prevailed in seeds. Aluminum contented in cockscomb leaves $(215.00 \pm 5.38 \mu \mathrm{g} / 100 \mathrm{~g})$ was almost 5 times higher than in flowers $(44.00 \pm 1.10 \mu \mathrm{g} / 100 \mathrm{~g})$. Cockscomb seeds contained 2.6 times less iron than their roots that was only $81.00 \pm 2.02 \mu \mathrm{g} / 100 \mathrm{~g}$.

The prevailing microelement in cockscomb stems was zinc to the amount of $5.70 \pm 0.14 \mu \mathrm{g} / 100 \mathrm{~g}$. Iron content in this part of the herb was somehow less that is $4.60 \pm$ $0.12 \mu \mathrm{g} / 100 \mathrm{~g}$. At the same time, the results of our experiment showed zinc accumulation most in roots (53.00 \pm $1.33 \mu \mathrm{g} / 100 \mathrm{~g})$. Identically high molybdenum content was found in cockscomb roots and leaves that is $0.21 \pm 0.01 \mu \mathrm{g} / 100 \mathrm{~g}$. Manganese content prevailed in leaves $(27.00 \pm 0.68 \mu \mathrm{g} / 100 \mathrm{~g})$, copper content prevailed in flowers $(2.00 \pm 0.05 \mu \mathrm{g} / 100 \mathrm{~g})$ and that of nickel prevailed in seeds of this plant $(0.54 \pm 001 \mu \mathrm{g} / 100 \mathrm{~g})$.

The content of heavy metals in all tested samples of cockscomb raw material met the requirements of Ukrainian Pharmacopoeia never exceeding acceptable limits for medicinal raw material.

\section{Conclusions}

1. According to this research in roots, leaves, stems, flowers, and seeds of cockscomb were identified and quantitatively determined 6 macroelements, 8 microelements, and 5 heavy metals by atomic absorption spectroscopy.

2 . The high content of mineral elements was found in the roots and leaves of the tested plant $-10513.52 \pm 262.84 \mu \mathrm{g} / 100 \mathrm{~g}$ and $11580.54 \pm 289.51 \mu \mathrm{g} / 100 \mathrm{~g}$ respectively. In all raw material samples potassium, calcium, and magnesium prevailed which were mostly accumulated in cockscomb leaves that is $7000.00 \pm 175.00 \mu \mathrm{g} / 100 \mathrm{~g}, 2430.00 \pm 60.75$ $\mu \mathrm{g} / 100 \mathrm{~g}$, and $1080.00 \pm 27.00 \mu \mathrm{g} / 100 \mathrm{~g}$ respectively. Among microelements iron dominated in roots and seeds $(210.00 \pm 5.25 \mu \mathrm{g} / 100 \mathrm{~g}$ and $81.00 \pm 2.02 \mu \mathrm{g} / 100 \mathrm{~g}$ respectively), aluminum in leaves and flowers (215.00 \pm 2.25 $\mu \mathrm{g} / 100 \mathrm{~g}$ and $44.00 \pm 1.10 \mu \mathrm{g} / 100 \mathrm{~g}$ respectively). Zinc was a prevailing element in cockscomb stems (5.70 \pm $0.14 \mu \mathrm{g} / 100 \mathrm{~g})$. The obtained results correlate with data from the literature.

3. The content of heavy metals in cockscomb raw material met the requirements of Ukrainian Pharmacopoeia.

Prospects for further research. The obtained results will be used in the standardization of cockscomb raw material and in the development of medicines on the basis of this raw material.

Conflicts of interest: authors have no conflict of interest to declare. Конфлікт інтересів: відсутній.

Information about authors:

Deyneka A. S., PhD-student of the Department of Chemistry of Natural Compounds and Nutritiology, National University of Pharmacy, Kharkiv, Ukraine.

ORCID ID: 0000-0003-3765-9290

Protska V. V., PhD, Assistant of the Department of Chemistry of Natural Compounds and Nutritiology, National University of Pharmacy, Kharkiv, Ukraine.

ORCID ID: 0000-0002-2439-138X

Zhuravel I. O., PhD, DSc, Professor of the Department of Chemistry of Natural Compounds and Nutritiology, National University of Pharmacy, Kharkiv, Ukraine.

ORCID ID: 0000-0001-8092-733X

Kyslychenko O. A., PhD, DSc, Associate Professor of the Department of Pharmacognosy, National University of Pharmacy, Kharkiv, Ukraine. ORCID ID: 0000-0002-9667-2535

Kuznietsova V. Yu., PhD, DSc, Associate Professor of the Department of Chemistry of Natural Compounds and Nutritiology, National University of Pharmacy, Kharkiv, Ukraine.

ORCID ID: 0000-0002-4146-689X

\section{Відомості про авторів:}

Дейнека А. С., аспірант каф. хімії природних сполук і нутриціології, Національний фармацевтичний університет, м. Харків, Україна. Процька В. В., канд. фрарм. наук, асистент каф. хімії природних сполук і нутриціології, Національний фармацевтичний університет, м. Харків, Україна.

Журавель І. О., д-р фарм. наук, професор каф. хімії природних сполук і нутриціології, Національний фармацевтичний університет, м. Харків, Україна.

Кисличенко О. А., д-р фарм. наук, доцент каф. фармакогнозії, Національний фармацевтичний університет, м. Харків, Україна Кузнєцова В. Ю., д-р фарм. наук, доцент каф. хімії природних сполук і нутриціології, Національний фармацевтичний університет, м. Харків, Україна.

Сведения об авторах:

Дейнека А. С., аспирант каф. химии природных соединений и нутрициологии, Национальный фармацевтический университет, Харьков, Украина.

Процкая В. В., канд. фрарм. наук, ассистент каф. химии природных соединений и нутрициологии, Национальный фармацевтический университет, г. Харьков, Украина. 
Журавель И. А., д-р фарм. наук, профессор каф. химии природных соединений и нутрициологии, Национальный фармацевтический университет, г. Харьков, Украина.

Кисличенко А. А., д-р фарм. наук, доцент каф. фрармакогнозии, Национальный фармацевтический университет, г. Харьков, Украина. Кузнецова В. Ю., д-р фарм. наук, доцент каф. химии природных соединений и нутрициологии, Национальный фармацевтический университет, г. Харьков, Украина.

\section{References}

[1] Adegbaju, O. D., Otunola, G. A., \& Afolayan, A. J. (2019). Potential of celosia species in alleviating micronutrient deficiencies and prevention of diet-related chronic diseases: A review. AIMS Agriculture and Food, 4(2), 458-484. https://doi.org/10.3934/AGRFOOD.2019.2.458

[2] Al-Fartusie, F. S., \& Mohssan, S. N. (2017). Essential Trace Elements and Their Vital Roles in Human Body. Indian Journal of Advances in Chemical Science, 5(3), 127-136.

[3] Pavlenko-Badnaoui, M., Protska, V., \& Zhuravel, I. (2019). The study of the mineral composition of Heliopsis helianthoides. Norwegian Journal of development of the International Science, (6-1), 50-53.

[4] Sousa, C., Moutinho, C., Vinha, A. F., \& Matos, C. (2019). Trace Minerals in Human Health: Iron, Zinc, Copper, Manganese and Fluorine. International Journal of Science and Research Methodology, 13(3), 57-80.

[5] Soetan, K. O., Olaiya, C. O., \& Oyewole, O. E. (2010). The importance of mineral elements for humans, domestic animals and plants: A review. African Journal of Food Science, 4(5), 200-222.

[6] Oves, M., Saghir, K. M., Huda, Q. A., Nadeen F. M., \& Almeelbi T. (2016). Heavy Metals: Biological Importance and Detoxification Strategies. Journal of Bioremediation \& Biodegradation, 7(2), 334. https:// doi.org/10.4172/2155-6199.1000334

[7] Sharma, R. K., \& Agrawal, M. (2005). Biological effects of heavy metals: an overview. Journal of environmental biology, 26(2 Suppl), 301-313.

[8] Trace Elements and Metals. (2019). In LiverTox: Clinical and Research Information on Drug-Induced Liver Injury. National Institute of Diabetes and Digestive and Kidney Diseases.

[9] State Enterprise Ukrainian Scientific Pharmacopoeial Center of Medicines Quality (2014). Derzhavna Farmakopeya Ukrayiny [The State Pharmacopoeia of Ukraine] (Vol. 1, 2nd ed.). Kharkiv: State Enterprise Ukrainian Scientific Pharmacopoeial Center of Medicines Quality. [in Ukrainian].

[10] Verkhovna Rada of Ukraine. (1997, December 23). Pro osnovni pryntsypy ta vymohy do bezpechnosti ta yakosti kharchovykh produktiv. Zakon Ukrainy vid 23.12.1997 No. 771/97-VR [On Quality and Safety of Food Products and Food Raw Materials (No. 771/97-VR)]. https://zakon.rada.gov.ua/laws/show $/ 771 / 97-\%$ D0\%B2\%D1\%80?lang=en\#Text

[11] Gaibimei, P., Yousuf, O., Singh, A., \& Devi, N. M. (2018). A study on phytochemical screening of Celosia argentea var. cristata inflorescence extract. The Pharma Innovation Journal, 7(10), 284-287.

[12] Sayeed, R., Thakur, M., \& Gani, A. (2020). Celosia cristata Linn. flowers as a new source of nutraceuticals- A study on nutritional composition, chemical characterization and in-vitro antioxidant capacity. Heliyon, 6(12), e05792. https://doi.org/10.1016/j.heliyon.2020.e05792

[13] Sultan F. I. (2018). Chromatographic Separation and Identification of Many Fatty acids and Phenolic Compounds from Flowers of Celosia cristata L. and Its Inhibitory Effect on Some Pathogenic Bacteria. Australian Journal of Basic and Applied Sciences, 12(7), 25-31. https:// doi.org/10.22587/ajbas.2018.12.7.4

[14] Oyeyinka, B. O., \& Afolayan, A. J. (2020). Potentials of Musa Species Fruits against Oxidative Stress-Induced and Diet-Linked Chronic Diseases: In Vitro and In Vivo Implications of Micronutritional Factors and Dietary Secondary Metabolite Compounds. Molecules, 25(21), 5036. https://doi.org/10.3390/molecules25215036

[15] Surse, S. N., Shrivastava, B., Sharma, P., Sharma, J., \& Gide P. S. (2014). Pharmacognostic Standardisation of Whole Plant of Celosia argentea, var. cristata (L). International Journal for Pharmaceutical Research Scholars, 3(3), 387-392.

[16] Malomo, S. O., Ore, A., \& Yakubu, M. T. (2011). In vitro and in vivo antioxidant activities of the aqueous extract of Celosia argentea leaves. Indian journal of pharmacology, 43(3), 278-285. https://doi. org/10.4103/0253-7613.81519

[17] Varadharaj V., Muniyappan J. (2017). Phytochemical and Phytotherapeutic Properties of Celosia species-A Review. International Journal of
Pharmacognosy and Phytochemical Research, 9(6), 820-825. https:/l doi.org/10.25258/phyto.v9i6.8185

[18] Adegbaju, O. D., Otunola, G. A., \& Afolayan, A. J. (2019). Proximate, mineral, vitamin and anti-nutrient content of Celosia argenteaat three stages of maturity. South African Journal of Botany, 124, 372-379. https://doi.org/10.1016/i.sajb.2019.05.036

[19] Fayaz, M., Bhat, M. H., Kumar, A., \& Kumar A. J. (2019). Phytochemical Screening and Nutritional Analysis of Some Parts of Celosia argentea L. Chemical Science Transactions, 8(1), 12-19. https://doi. org/10.7598/cst2019.1561

[20] Kyslychenko, O., Protska, V., \& Zhuravel, I. (2019). Phytochemical research of vagrant Parmelia thalli as a prospective source of certain nutrients. Norwegian Journal of development of the International Science, (30), 44-49. 